\title{
Improvement of methods for determining the cost of design documentation in construction
}

\author{
Tatiana Dobysheva ${ }^{1, *}$, and Ekaterina Gladkova ${ }^{2}$ \\ ${ }^{1}$ Irkutsk National Research University, 664074, Lermontova str., 83, Irkutsk, Russia \\ ${ }^{2}$ Sibstroitekhmontazh Ltd., 666037, Stroiteley i Montazhnikov avenue, 11/2, Shelekhov, Russia
}

\begin{abstract}
The problems of definition of the cost of design in construction are considered in the article. The existing regulatory documentation for determining the value of construction products on the territory of the Russian Federation is analyzed. A comparative analysis of the currently used methods for calculating the cost of designing is executed. The advantages and disadvantages of each method are considered, and the necessity of transformations in the sphere of determining the cost of design works is substantiated. The ways of increasing accuracy of calculation of the cost of design in construction are suggested, including the use of the territorial coefficient in calculations when utilizing the method of dependence on the natural indicators of the design objects. It is revealed that the use of this coefficient significantly increases the accuracy of calculations. For the method of calculating the cost of design as a percentage of the total cost of construction, it is proposed to clarify the methodology for calculating the cost of construction of multi-apartment buildings according to the enlarged construction price standards. It is proved that today it is impossible to replace the value of individual structural elements of an object in the event of differences in the design solutions with the solutions represented by similar objects in the collection of the construction price standards. The ways of solving these issues by the use of collections of standards for the price of construction solutions are outlined. The authors are convinced that the improvement of methods for calculating the cost of design products will improve the efficiency of investments in the construction industry.
\end{abstract}

\section{Introduction}

In the context of optimizing the expenditure of budgetary and extra-budgetary funds, there is a need to improve the system of pricing in construction. Currently, the Russian Federation is reforming the system of pricing in this industry [5-6, 9]. But not only the regulatory framework used when determining the cost of construction needs improvement, but also the regulatory framework utilized when calculating the cost of design in the construction industry.

The impact of the cost of design work on the final cost of investment and construction processes cannot be overemphasized. The estimate documentation for design work is the

\footnotetext{
*Corresponding author: dobishevatv@mail.ru
} 
basis not only for setting contractual design prices, but also serves as a benchmark for determining the maximum price for the cost of design, and mutual settlements between the customer and the designer took place on the basis of the estimate documentation. However, at present, there is no substantiated and methodologically objective methodology for determining the cost of design.

Completely free pricing is not used in foreign practice. In these countries, the state indirectly affects demand, supply, and, consequently, prices. In global practice, as a rule, the maximum possible prices and the lowest possible prices are established. In the United States, for example, there is no the estimate normative base approved at the state level, but there are annual collections of single and consolidated construction quotations that are used regardless the departmental ownership. In the UK, construction companies have the right to create individual unit prices that ultimately can affect the cost of final construction products and reduce this indicator that increases the competitiveness of contractors. Another feature of foreign countries in determining the cost of construction and design is the fact, that abroad, the main principle of the cost of the project is the determination of reliability, and therefore, in determining the cost of construction, the enlarged indicators of the construction costs are used at all stages of investment [8, 11-15].

In foreign countries, design is recognized as qualitative, if the possibility of adaptation to technological and technical innovations without radical reconstruction for at least 6-8 years after the start of operation is taken into account. In this case, it is justified to increase a part of the costs addressed to design, since this factor provides for an increase in the efficiency of capital investments as a whole [12].

In accordance with [1], the total cost of construction is determined by the Consolidated Estimate of the Construction Costs. This estimate document consists of 12 chapters. The costs included in the Chapter 12 of the Consolidated Estimate of Construction Costs are regulated by the Government Decree No. 563 of May 12, 2017.

Thus, the Chapter 12 of the Consolidated Estimate calculation, together with other costs, includes the costs of the design work. And these costs should be determined at the stage of preparation of the investment justification, that is, at the pre-project stage.

\section{Materials and Methods}

Currently, three methods for determining the cost of design are used in the Russian Federation [2]:

The base prices for design works contain all the costs of design organizations, accounted for in the production costs of these organizations in accordance with [3].

The existing methods for determining the cost of design of the construction products differ from the position of methodology, and application of each of its options gives a different value of the indicator of the contractual design price.

When analyzing the existing methods of calculating the cost of designing for the representative objects of different purposes, it is revealed that the design cost can vary from 33 to $60 \%$ [10]. Such a difference in the cost of designing the same construction objects is unacceptable in the conditions of maximum cost optimization of both budgetary and extrabudgetary levels.

The Table 1 presents a comparative analysis of methods for determining the cost of designing. 
Table 1. Comparative analysis of methods for determining the cost of design works.

\begin{tabular}{|c|c|c|c|}
\hline $\begin{array}{l}\text { The name of } \\
\text { the method for } \\
\text { determining } \\
\text { the cost of } \\
\text { designing }\end{array}$ & Normative documents & Procedure of calculation & $\begin{array}{l}\text { Advantages and } \\
\text { disadvantages of the } \\
\text { method }\end{array}$ \\
\hline $\begin{array}{l}\text { Depending on } \\
\text { the natural } \\
\text { indicators of } \\
\text { the designing } \\
\text { objects }\end{array}$ & $\begin{array}{l}\text { 1. Existing sectoral and } \\
\text { specialized sections of the } \\
\text { Collection of prices for } \\
\text { design works in } \\
\text { construction of } 1987- \\
1990 \text {, reduced to the price } \\
\text { level as of } 01.01 .1991 \text {. } \\
\text { 2. Directories of basic } \\
\text { prices (DBP) for design } \\
\text { works in construction of } \\
\text { 2003-2004, reduced to the } \\
\text { price level as of } \\
01.01 .2001 \text {. } \\
\text { 3. Directories of basic } \\
\text { prices for design works in } \\
\text { construction of } 2009 \text { - } \\
\text { 2017, reduced to the level } \\
\text { of prices as of } \\
01.01 .2001 \text {. }\end{array}$ & $\begin{array}{l}\text { The following formula is } \\
\text { used in the calculation: } \\
\mathrm{C}=(\mathrm{a}+\mathrm{b} \times \mathrm{X}) \times \mathrm{K}(1) \\
\text { where: } \\
\mathrm{a}, \mathrm{b} \text { - constants for a } \\
\text { certain interval of the } \\
\text { main indicator of the } \\
\text { object of design, taken } \\
\text { from the tables of } \\
\text { directories, in thousands } \\
\text { rubles; } \\
\mathrm{X} \text { - the main indicator of } \\
\text { the object of design; } \\
\mathrm{K} \text { is the total coefficient } \\
\text { [2]. }\end{array}$ & $\begin{array}{l}\text { Advantages: } \\
\text { For today, it is the most } \\
\text { convenient and reliable } \\
\text { method of determining } \\
\text { the price of design } \\
\text { works. About } 250 \\
\text { directories of basic } \\
\text { prices for the design of } \\
\text { the most types of } \\
\text { objects have been } \\
\text { developed. } \\
\text { Directories can be used } \\
\text { to determine the cost of } \\
\text { design for the objects, } \\
\text { to be constructed with } \\
\text { budgetary funding. } \\
\text { Disadvantages: } \\
\text { There are no directories } \\
\text { for calculating the cost } \\
\text { of design for some } \\
\text { individual construction } \\
\text { projects. } \\
\text { The regional } \\
\text { coefficient, which } \\
\text { allows passing from the } \\
\text { prices of the base } \\
\text { district of the Moscow } \\
\text { region to the prices of } \\
\text { constituent entities of } \\
\text { the Russian Federation, } \\
\text { has not been developed. }\end{array}$ \\
\hline $\begin{array}{l}\text { As a percentage } \\
\text { of the total cost } \\
\text { of construction }\end{array}$ & $\begin{array}{l}\text { 1. Directories of basic } \\
\text { prices for design works in } \\
\text { construction of } 2003 \text { - } \\
2004 \text {, reduced to the price } \\
\text { level as of } 01.01 .2001 \text {. } \\
2 \text {. Directories of basic } \\
\text { prices for design works in } \\
\text { construction of 2009- } \\
2017 \text {, reduced to the level } \\
\text { of prices as of } \\
01.01 .2001 \text {. }\end{array}$ & $\begin{array}{l}\text { The following formula is } \\
\text { used in the calculation: } \\
\mathrm{C}=\mathrm{C}_{01} \times \mathrm{Ki}(2) \\
\text { where } \mathrm{C}_{01} \text { is the base } \\
\text { price of the project } \\
\text { documentation as of } \\
01.01 .2001 \text {; } \\
\mathrm{Ki} \text { - coefficient reflecting } \\
\text { the inflationary processes }\end{array}$ & $\begin{array}{l}\text { Advantages: } \\
\text { This method can be } \\
\text { used to determine the } \\
\text { cost of design for the } \\
\text { objects, the } \\
\text { construction of which } \\
\text { has budgetary } \\
\text { financing. } \\
\text { Disadvantages: } \\
\text { Insufficient accuracy of } \\
\text { calculations at the pre- }\end{array}$ \\
\hline
\end{tabular}




\begin{tabular}{|c|c|c|c|}
\hline & & 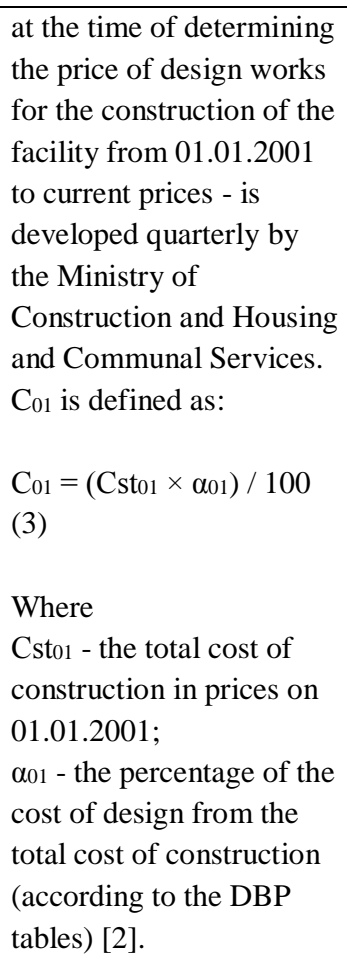 & $\begin{array}{l}\text { design stage when } \\
\text { determining the cost of } \\
\text { construction for larger } \\
\text { collections or similar } \\
\text { objects. }\end{array}$ \\
\hline $\begin{array}{l}\text { Based on the } \\
\text { labor costs } \\
\text { (costs) of the } \\
\text { design } \\
\text { organization }\end{array}$ & $\begin{array}{l}\text { Methodical guidelines on } \\
\text { the procedure for the } \\
\text { development of state } \\
\text { budget standards } \\
\text { "Directories of basic } \\
\text { prices for design work in } \\
\text { construction" approved by } \\
\text { the Ministry of } \\
\text { Construction and Housing } \\
\text { and Communal Services } \\
\text { of the Russian Federation } \\
\text { by Order No. } 406 \text { / of } \\
\text { June } 4,2015\end{array}$ & $\begin{array}{l}\text { Calculation of the cost of } \\
\text { design works at the cost } \\
\text { based on actual labor } \\
\text { costs, and the current } \\
\text { level of profitability of the } \\
\text { project organization. } \\
\text { For determining the } \\
\text { specifications of the labor } \\
\text { intensity of design works, } \\
\text { the following methods are } \\
\text { proposed in the } \\
\text { guidelines: } \\
\text { - expert method; } \\
\text { - statistical method; } \\
\text { - calculation and analysis } \\
\text { method [2]. }\end{array}$ & $\begin{array}{l}\text { Advantages: } \\
\text { The method is } \\
\text { convenient for the } \\
\text { designer as he expertly } \\
\text { himself determines the } \\
\text { actual time of } \\
\text { participation of } \\
\text { specialists in the } \\
\text { development of the } \\
\text { project. } \\
\text { Disadvantages: } \\
\text { Lack of federal-level } \\
\text { labor standards for } \\
\text { design. }\end{array}$ \\
\hline
\end{tabular}

\section{Results}

The study showed that all methods of determining the cost of design have some drawbacks. So in the method, depending on the natural indicators, there is no a single district coefficient for recalculating the cost of design works from the prices of the base district of the Moscow Region into the prices of regions of the Russian Federation. Such coefficients are extremely necessary, since the cost of construction, including the cost of design, varies considerably by regions of the Russian Federation. To recalculate the cost of construction works, the territorial coefficients for each region are quarterly developed and issued by the 
Ministry of Construction and Housing and Utilities, and are applied by estimators in the preparation of estimates, while in order to calculate the cost of design, the Ministry of Construction quarterly updates the single factor for the whole of Russia to recalculate the design cost from the base prices as of 01.01.2001 to current prices. In this case, in order to differentiate the cost of designing by regions, the estimators are forced to use district coefficients that take into account the difference in the cost of material consumption of the population in the regions of the country that should be charged only on wages. However, the cost of design consists of direct costs, overheads and profits of the design organization [3]. The salary of designers is only one of the five elements of the cost of design products, along with material costs, depreciation of the fixed assets, deductions on social needs and other costs [4], and is just 18 to $30 \%$ of the total actual cost of construction products [10]. Thus, it was revealed that the application of the district coefficient for the entire design cost is methodically incorrect.

We propose to introduce the territorial coefficient $\mathrm{K}_{\mathrm{tr}}$ in the formula that is used for determining the cost of design, depending on the natural indicators. Then formula 1 will have the following form:

$$
\mathrm{C}=(\mathrm{a}+\mathrm{b} \times \mathrm{X}) \times \mathrm{K} \times \mathrm{K}_{\text {tr }}
$$

As for the second method of determining the cost of design as a percentage of the total cost of construction, as in the Table 1, there is a lack of inaccuracy in calculations for the enlarged directories. Currently, there are insufficient numbers of the enlarged directories for the estimate and regulatory framework in construction. There is only one approved directory "Automobile Roads" from the group of consolidated standards for the price of constructive decisions of the standards of design work prices, and a group of 21 collections for aggregate construction price norms for non-production facilities and engineering infrastructure of the Estimated Price Standards-2017, approved in 2017. There are no enlarged collections for all for production objects, and this, respectively, makes it difficult to calculate the total cost of such facilities at the pre-design stage, and thus makes it difficult to calculate the design cost. With regard to the application of the existing estimated price standards, the design decision of the facility does not always coincide with the design decision of the representative object in the Estimated Price Standards-2017. The issues of replacement of the cost of certain noncoincident constructive solutions could be solved if there is a complete list of collections of standards of design work prices, but at present this is impossible due to the lack of developed and approved collections of standards of design work prices. As a result, a fairly accurate calculation of the total cost of construction based on the Estimated Price Standards-2017 is impossible. In addition, when using the Estimated Price Standards-2017 "Residential Buildings", there is no method for recalculating the cost of $1 \mathrm{~m}^{2}$ of the total area of the apartment to $1 \mathrm{~m}^{2}$ of the total area of the facility, and therefore there is no possibility of calculating the cost of construction of the apartment building with staircases. It is also necessary to note the insufficient number of norms included in the collections, which significantly narrows the possibilities of their application for some objects of design.

In course of the comparative analysis of the cost of construction in the city of Irkutsk according to the fact sheet of the Information Bulletin "Indices of prices in construction" for the 3rd quarter of 2017 (IPC) and the cost of construction of similar facilities for representative objects in the Estimated Price Standards-2017 (EPS-2017) with conversion to the Irkutsk prices for the 3rd quarter of 2017, carried out in the Table 2, an overestimate of the cost of construction of facilities based on the collections of the aggregated standards of construction prices from $15.96 \%$ to $31.3 \%$ has been identified.

Table 2. Comparative analysis of the cost of construction of facilities. 


\begin{tabular}{|c|c|c|c|}
\hline \multirow[t]{2}{*}{ Name of the object } & \multicolumn{2}{|c|}{$\begin{array}{l}\text { Cost of the construction of the } \\
\text { facility without taking into } \\
\text { account design and survey } \\
\text { works, thousand rubles } / \mathrm{m}^{2}\end{array}$} & \multirow{2}{*}{$\begin{array}{c}\text { Relative } \\
\text { deviation } \\
, \%\end{array}$} \\
\hline & $\begin{array}{c}\text { IPC, the } 3^{\text {rd }} \\
\text { quarter of } 2017\end{array}$ & EPS-2017 & \\
\hline 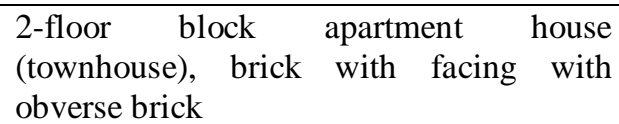 & 24.77 & 36.05 & 31.3 \\
\hline $\begin{array}{l}\text { 8-floor residential brick building with a } \\
\text { monolithic frame (monolithic reinforced } \\
\text { concrete foundation) }\end{array}$ & 35.08 & 44.82 & 21.73 \\
\hline $\begin{array}{l}\text { 9-floor residential brick building with a } \\
\text { monolithic frame (pile foundations) }\end{array}$ & 36.61 & 43.56 & 15.96 \\
\hline
\end{tabular}

It should be noted that the method of determining the value based on the enlarged collections in comparison with the estimates shows an overestimation not only in new construction, but also during reconstruction and overhaul, and relative deviation in calculating the cost of overhaul is about 50\% [7].

Regarding the third method of determining the cost of design, it is revealed that the lack of federal-level standards for the duration of design of construction objects makes it impossible to use this method when designing facilities, in construction of which federal budget funds are involved. Consequently, there is a need to develop a new, justified system of labor intensity standards. The norms of labor intensity of designing will allow reliably determining the cost of the design production as a part of the total cost of construction.

\section{Discussion}

Taking into account the obtained results, it is possible to form the basic measures for improving the pricing system in construction, in particular when calculating the cost of design work by making the following:

1. To include the territorial coefficient in the formula for calculating the cost of design, depending on the natural indicators of the design objects.

2. To develop a full range of collections of the enlarged norms for the price of constructive solutions, for the application of these collections in clarifying the constructive decisions of EPS.

3. To develop collections of the enlarged standards for construction prices for production facilities.

4. To expand the nomenclature of existing collections of EPS by including additional representative objects.

5. To develop a method for recalculating the cost of $1 \mathrm{~m}^{2}$ of the total area of the apartment to $1 \mathrm{~m}^{2}$ of the total area of the facility in the Estimated Price Standards-2017 "Residential Buildings".

6. To clarify the construction price standards included in the Estimated Price Standards2017 "Residential Buildings".

7. To develop and approve at the federal level the design labor intensity standards that could be used throughout the Russian Federation. 


\section{Conclusion}

Thus, in the context of reforming the pricing system in construction in the Russian Federation, the ways we proposed in order to improve the accuracy of the design cost calculations will allow optimizing the costs of the customer for calculation of design documentation. This in turn will affect the amount of investments in the construction of facilities financed from the budgets of all levels, and from extra-budgetary funds.

The proposed set of measures to improve the methods of calculating the cost of the design products will contribute to improving efficiency of investments in construction.

It is important to note that increasing accuracy of design cost calculations can contribute to the development of innovative economy, to improve the quality of design products, and to reduce the cost price of construction, which entails a reduction in the cost of construction facilities.

\section{References}

1. Methods for determining the value of construction products in the territory of the Russian Federation, (MDS 81-35. 2004) (Gosstroy, Moscow, 2004)

2. Methodical instructions on the application of reference books of basic prices for design works for construction. Approved by Order of the Ministry of Regional Development of the Russian Federation of December 29, 2009 N 620 (Moscow)

3. Methodological recommendations on the composition and accounting of costs included in the cost of design and survey products (works, services) for construction and the formation of financial results (MDS 81-15. 2000) (Gosstroy, Moscow, 2000)

4. Regulation on the composition of costs for the production and sale of products (works, services), included in the cost of products (works, services), and on the procedure for the formation of financial results that are taken into account when taxing profits. Decree of the Government of 5.08.92 No. 552 (Moscow)

5. S. A. Alekseev, Economics and Entrepreneurship, 9-1(86), 669-672 (2017)

6. O. Antonyan, E. N. Karpushko, A. S. Solovyov, Construction Economics, 4(46), 3-14 (2017)

7. O. Antonyan, N. R. Torchyan, Materials of the IV International Scientific and Practical Internet Conference, 121-127 (2017)

8. E. S. Dedyukhina, Izvestiya Vuzov. Investments. Building. Real Estate, 4(15), 26-32 (2015)

9. T. V. Dobysheva, K. N. Putsenko, Izvestiya Vuzov. Investments. Building. Real Estate, 1(4), 33-41 (2013)

10. A. S. Merzlyakova, Bulletin of the Ural Institute of Economics, Management and Law, 4, 48-54 (2017)

11. I. V. Yamshchikova, E. I. Naumov, Proceedings of the Irkutsk State Technical University, 3(50), 36-41 (2011)

12. P. C. A. Chan, D. Scott, and A. P. L. Chan, Journal of Construction Engineering and Management, 7, 153-155 (2004)

13. D. Arditi, M. Asce, A. Elhassan, Y. CengizToklu, Journal of Construction Engineering And Management, 126(5) (2002)

14. L. Shen, M. Asce, Y. Wu X. Zhang, Journal of Construction Engineering and Management, 137(6) (2011) 
15. L. Župová, Student conference of civil engineering and architecture, 1-6 (2012)

16. M. Tkáč, M. Sabolová, Information technology and society: interaction and interdependence, 217-278 (2015) 